UDC 94(470)“19"

Submitted: 31.03.2019

LBC 63.3(2)64

Accepted: 30.06 .2019

\title{
STATE AND THE COSSACKS: ON THE WAY TO PUBLIC SERVICE
}

\author{
German O. Macievskiy \\ Kuban State University of Physical Culture, Sports and Tourism, Krasnodar, Russian Federation
}

\begin{abstract}
Introduction. To date, members of the Cossack societies that have taken on the obligation to perform public service are involved in ensuring public order, protecting the state border and the environment and other activities. This study is devoted to the policy of the state aimed at transforming the revived Cossacks from their unpredictable social movement into a controlled part of the state structure. Methods and materials. The main sources for preparing the article were documents from the collections of acts of the President and Government of the Russian Federation, collections of the legislation of the Russian Federation, as well as the Order of the Government of the Russian Federation on the problems of the Cossacks and documents on their implementation stored in the State Archives of the Russian Federation. The methodological basis of the study was the principles of historicity, objectivity and system. Analysis. The study analyzes the chronology of events, the search for forms of the Cossack civil service, and interaction with various branches of the government. Results. The study concludes that between 1994 and 1998 the state sought and formalized the legal status of the Cossacks as a state structure bringing it into the state register of Cossack societies in the Russian Federation for state and other service. In addition, a legal framework was created for organizational and economic support of the Cossack societies included in the state register. By 1998, 10 Cossack Host societies, 5 Cossack divisions, 2 Cossack districts and 2 Cossack urban societies (Moscow and Saint Petersburg) had entered the state register.

Key words: modern Cossacks, revival of the Cossacks, state register of Cossack societies, public policy, public service.

Citation. Macievskiy G.O. State and the Cossacks: On the Way to Public Service. Vestnik Volgogradskogo gosudarstvennogo universiteta. Seriya 4. Istoriya. Regionovedenie. Mezhdunarodnye otnosheniya [Science Journal of Volgograd State University. History. Area Studies. International Relations], 2019, vol. 24, no. 4, pp. 164-172. (in Russian). DOI: https://doi.org/10.15688/jvolsu4.2019.4.14
\end{abstract}

УДК 94(470)“19”

Дата поступления статьи: 31.03.2019

ББК $63.3(2) 64$

Дата принятия статьи: 30.06.2019

\section{ГОСУДАРСТВО И КАЗАЧЕСТВО: НА ПУТИ К ГОСУДАРСТВЕННОЙ СЛУЖБЕ}

\author{
Герман Олегович Мациевский \\ Кубанской государственной университет физической культуры, спорта и туризма, \\ г. Краснодар, Российская Федерация
}

\begin{abstract}
Аннотация. В качестве объекта исследования избрана политика государства в отношении современного российского казачества в 1994-1998 годах. Цель работы - на основе обширного и репрезентативного круга документов органов власти и архивных источников выявить особенности государственной политики 을 трансформации возрождающегося казачества из малопредсказуемого и неуправляемого обществен훙 ного движения в государственную структуру, призванную нести государственную службу. В конце 1980-х ○ं начале 1990-х гг. с разрушением СССР и вхождением страны в перманентный всеобъемлющий кризис все активнее проявляются общественные силы, стремящиеся определить свое место и роль в новой действительности. К ним относится и движение за возрождение казачества, заявляющее о своем желании участвовать не только в общественной и культурной, но и экономической, и политической жизни общества. По оценкам экспертов, к этому времени в стране насчитывается до 5 млн потомков казаков или считающих себя казаками. В этой ситуации власть должна была не только определить, но и законодательно оформить свою политику (2) в отношении казачьего движения, исходя из необходимости стабилизации и регламентации общественно-
\end{abstract}


политической жизни, с учетом исторических традиций выстраивания логики взаимоотношений между государством и казачеством. В результате исследования делается вывод о том, что в 1994-1998 гг. государство пыталось определить, а затем законодательно оформить правовой статус казачьего движения, подготовить основу для несения членами казачьих обществ государственной и иной службы, а также включить эти общества в государственный реестр казачьих обществ в Российской Федерации. При этом активно оформлялась правовая основа экономической и иной поддержки казачьих обществ. К 1998 г. в госреестре состояли 10 войсковых обществ, 5 отделов, 2 округа и 2 городских общества.

Ключевые слова: современное казачество, возрождение казачества, государственный реестр казачьих обществ, государственная политика, государственная служба.

Цитирование. Мациевский Г. О. Государство и казачество: на пути к государственной службе // Вестник Волгоградского государственного университета. Серия 4, История. Регионоведение. Международные отношения. - 2019. - Т. 24, № 4. - C. 164-172. - DOI: https://doi.org/10.15688/jvolsu4.2019.4.14

Введение. Процессы модернизации в СССР, а позднее в России во второй половине 1980-х - 1990-х гг. охватили фактически все грани жизни общества, породив комплекс проблем общегосударственного масштаба. Глобальные перемены «превращают» Союз Советских Социалистических Республик в Российскую Федерацию: «перестройка» второй половины 1980-х гг.; «роспуск» Союза в 1991 г.; «демонтаж» социализма и экономические реформы 1992 и последующих годов; «утеря» советской власти и расстрел Дома Советов осенью 1993 года. Всеобъемлющий кризис политической, идеологической и социальной сторон жизни общества, активизировав социально-политические процессы, стимулировал многих людей к поиску твердых идейных оснований, не подвергающихся сомнению истин и устойчивых мировоззренческих ценностей, ко всему тому, что помогло бы сохранить смысложизненные устои и духовно-нравственные ориентиры, определить адекватное отношение к происходящему. В этих условиях начинает заявлять о себе движение за возрождение казачества, активно осуществляющее поиск своего места и роли в новой российской государственности.

Согласно данным Института этнологии и антропологии РАН к началу 1990-х гг. в исторических казачьих регионах (Дон, Кубань, Терек) жителей, считавших себя потомками казаков, было до 10-15\% от всех жителей, в Сибири и на Дальнем Востоке - около 1$5 \%$ [4, с. 113-114]. Всего же в России считали себя потомками казаков по прямой линии около 5 млн чел. [4, с. 114], или до 3 \% от всего населения страны.

При этом представители движения за возрождение казачества заявляют о своем желании все активнее участвовать в экономической, политической, культурной и социальной жизни государства. Они создают общественные организации и союзы, «войсковые» общества, выступают с требованиями защиты русскоязычного населения в многонациональных регионах, с оружием в руках участвуют в политических, религиозных и межнациональных конфликтах как внутри страны, так и за ее пределами.

Для придания возрождающемуся казачеству «целесообразности» и нужной «направленности» главнокомандующим Вооруженными силами СНГ маршалом Е. Шапошниковым направляется Президенту РФ Б. Ельцину Письмо № 312/2/1 от 11 января 1992 г. «О проблеме возрождения Казачества в России», где указывается, что данное «движение казаков» является по своему характеру «неуправляемым», а потому может играть негативную роль в общественной жизни страны [2, л. 12]. В связи с этим, как считает Е. Шапошников, необходимо организовать совместно с Госкомитетом РФ по обороне и безопасности встречу с казачьим руководством и рассмотреть на ней вопросы, препятствующие казачьему возрождению, а также касающиеся возможности создания в Вооруженных силах и подразделениях внутренних войск России казачьих соединений и частей, военных учебных заведений, готовящих кадры для казачьих подразделений, организаций и т. д. [2, л. 2]. Вскоре, 15 июня этого же года, выходит Указ Президента РФ № 632 «О мерах по реализации закона Российской Федерации “О реабилитации репрессированных народов в отношении казачества"», а 16 июля - Постановление Верховного совета № 3321-1 «О реабилита- 
ции казачества», где впервые говорится о возможности несения казаками воинской и, шире, государственной службы. С этого времени государство начинает последовательный поиск путей «превращения» казачества в «управляемую и контролируемую» структуру, в том числе за счет привлечения его к государственной и иной связанной с ней службе.

В связи с этим статья будет посвящена государственной политике в отношении возрождающегося казачества, так как именно государство всегда играло и продолжает играть исключительную роль в определении места и роли казачества в российской действительности.

Методы и материалы. Хронологические рамки работы ограничиваются 19941998 гг, так как в этот период власть активно осуществляет поиск и законодательно оформляет основные подходы к формам и содержанию госслужбы современного казачества. В историографии рассматриваются отдельные аспекты данной проблемы, однако чаще всего лишь в рамках политологического или социологического подхода $[1 ; 5 ; 19]$. Целостного анализа процесса перехода казачества к госслужбе в рассматриваемый период не предпринимается. Основными источниками для подготовки статьи стали документы из собраний актов Президента и Правительства РФ, собраний законодательства РФ, а также Поручения Правительства РФ по проблемам казачества и документы по их выполнению, хранящиеся в Государственном архиве Российской Федерации. Методологической основой исследования стали принципы историчности, объективности и системности, предполагающие анализ исследуемых явлений и процессов как изменяющихся и взаимодействующих во времени и пространстве.

Анализ. Постановление Правительства Российской Федерации № 355 «О концепции государственной политики по отношению к казачеству» [13], принятое 22 апреля 1994 г., стало одним из первых ключевых документов рассматриваемого периода, в котором заявлялись основные направления государственной политики в отношении возрождавшегося казачества. В нем, в частности, отмечалось, что казаки России исторически всегда находились на государственной службе и это во многом предопределило их традиции, культуру и повседневную жизнь. В связи с этим государство готово было оказывать финансовую, материальную и иную поддержку процессу возрождения казачества в качестве государственной структуры, что, в свою очередь, должно было сказаться на более динамичном становлении новой российской государственности и укреплении ее обороноспособности и безопасности. Минобороны РФ согласно Постановлению должно было подготовить нормативные документы, на основании которых члены казачьих обществ должны были привлекаться к прохождению воинской службы. Однако, как особо подчеркивалось в Постановлении, это не должно было означать создания в Вооруженных силах каких либо новых («казачьих») видов войск (Приложение № 1 к директиве 1-го ЗМО №3 15/4/295 от 24 января 1996 г.). В п. 2. Постановления Министерству Российской Федерации по делам национальностей и региональной политики (далее-Миннац России) ставилась задача до 1 июня 1994 г. сформировать Комплексную государственную программу поэтапного экономического и культурного возрождения казачества, а также подготовить проекты постановлений Правительства РФ о возможности оказания государственной помощи, предоставления земли и льгот тем казакам, которые пожелают переселиться в приграничные районы [13]. Этому же министерству поручалось организационно обеспечить возможность ведения с 1 июля 1994 г. «государственного регистра казачьих обществ» в России и помочь казакам организовать и провести до 1 октября 1994 г. Всероссийский (объединительный) казачий круг [13]. В целях реализации данных задач в системе Миннаца России был сформирован Департамент по делам казачества [11]. Видимо, именно работники этого Департамента подготовили «Предложения по созданию и использованию казачьих объединений в Российской Федерации» [2, л. 107-108], в которых, наряду с прочим, отмечалось, что вместо общественных казачьих организаций необходимо ввести особую государственную регистрацию территориальных объединений казачества (войска, округа, отделы, станицы, хутора) в виде Государственного регистра казачьих войск [2, л. 107]. При этом предлагалось 
создать на территории страны до 11 войсковых казачьих объединений, в том числе на северо-западе - Псково-Балтийское казачье войско (Псковская и Ленинградская области, приграничье Калининграда); в центре и на востоке - новые Волжское (Волгское) и Дальневосточное казачьи войска (от Уссурийска до Сахалина, Камчатки и Курил), продумать возможность восстановления исторических Кубанского, Донского, Оренбургского, Сибирского, Забайкальского, Амурского и Терского казачьих войск [2, л. 108-109]. Основными функциями войск должны были стать: охрана госграницы, оказание содействия работе таможенного контроля, взаимодействие с органами внутренних дел по наведению и поддержанию правопорядка, стабилизации политических и социально-экономических процессов в регионах размещения.

В логике дальнейшего огосударствления движения президентским Указом от 1 июля 1994 г. № 1389 «О Совете по делам казачества при Президенте Российской Федерации» [12] был создан такой Совет, в котором были представлены: казачье руководство, Администрация Президента, Правительство РФ и некоторые другие федеральные органы исполнительной власти. Руководство Советом было возложено на Министра Миннаца России Н.Д. Егорова. Согласно Положению «О Совете по делам казачества при Президенте Российской Федерации», утвержденному президентским Указом от 1 декабря 1994 г. № 2141, Совет должен был готовить для Президента аналитические справки и доклады о складывающейся ситуации в казачьих организациях, обеспечивать управленческое взаимодействие казаков с различными властными структурами, предлагать и готовить проекты документов по реализации основных направлений госполитики в отношении казачьего движения [14].

Лето 1994 г. стало временем подготовки Проекта начального этапа реализации «Комплексной государственной программы поэтапного экономического и культурного возрождения российского казачества» [6, л. 80-146], в котором отмечалось, что количество социально и политически активных казаков в стране достигает 2 млн чел., имеющих собственные взгляды на свое место в российской действительности и идеологию своего дальнейшего развития [6, л. 83]. В Проекте говорилось, что государство рассматривает становление казачества в качестве «специфической части русского народа... имеющей многонациональные корни» [6, л. 85]. При этом особый акцент делался на традиционное стремление казаков нести государственную службу и иные обязанности перед государством взамен на поддержку и различные льготы от государства [6, л. 85]. Из вышесказанного явствует, что власть целенаправленно начинает превращать казачье общественное движение в некую государственную силовую структуру, получающую «поддержку и льготы» за несение госслужбы и иных связанных с ней обязанностей.

Почти параллельно с этим членами Совета по делам казачества готовится проект «Концепции государственной службы казачества» [8, л. 162-165], где приоритетными направлениями казачьей госслужбы заявлялись: воинская служба; участие в охране госграницы, с перспективой создания казачьих застав; взаимодействие с ОВД по обеспечению правопорядка и т. д. В Концепции также говорилось о приоритетности отказа казачества от участия в деятельности партий и политических движений $[8$, л. 164] в целях освобождения от влияния различных идей и идеологий и беспрекословного исполнения законов и распоряжений «законной власти» [8, л. 164]. В данном проекте наглядно проявилось стремление государства превратить казачество в контролируемую и управляемую силу, «верную только законам и законной власти».

В сентябре 1995 г. Миннацем России был подготовлен ряд документов под общим грифом «О проектах указов Президента и постановления Правительства РФ о российском казачестве» $[9$, л. 90]. В проекте президентского Указа «О видах государственной службы членов казачьих обществ» [9, л. 93-94] виды казачьей госслужбы были почти идентичными тем, которые формулировались в проекте «Концепции государственной службы казачества». В проекте президентского Указа «О льготах, предоставляемых членам казачьих обществ, взявших на себя обязательства по несению государственной службы» рассматривалась возможность предоставления казачьим обществам налоговых льгот, гарантировались неприкосновенность казачь- 
их земель, существенные скидки (до 50 \%) на оплату коммунальных услуг и др. [9, л. 97]. В то же время не вызывало сомнения то, что возрождаемое в таком виде казачье движение не будет иметь с историческим казачеством ничего общего, кроме сословных обязанностей и льгот. Данный комплект проектов президентских указов был передан заинтересованным министерствам и ведомствам на согласование. Вскоре в Миннац России стали возвращаться документы с предложениями и замечаниями по обсуждаемым вопросам. Министерством социальной защиты населения высказывалась полная поддержка самой идеи и видов госслужбы казачества. Более того, предлагалось даже расширить льготы за счет увеличения оплачиваемого отпуска и первоочередной установки телефонов у казаков, несущих госслужбу [9, л. 108]. Как отмечал первый заместитель директора федеральной пограничной службы РФ А. Тымко, казачество целесообразнее всего привлекать к госслужбе «в иррегулярных формированиях ФПС России», сочетая несение службы по охране госграниц с хозяйственной деятельностью и дополнительно стимулируя налоговыми льготами $[9$, л. 109]. Были и иные мнения. Так, из Государственного таможенного комитета (далее - ГТК) в адрес замминистра Миннаца России А.Г. Черненко было направлено письмо, подписанное заместителем председателя ГТК Г.М. Ануфриевым, содержащее категоричный протест возможной службе представителей казачьих обществ в таможенных органах [9, л. 119]. Вполне возможно, это было связано с некоторой «специфичностью» работы таможенных органов, не желающих допускать к своим «секретам» «чужих». Министерство финансов также высказалось против идеи особых льгот для казачьих обществ, но по несколько иным причинам. Соглашаясь с необходимостью нормативно-правового обеспечения госслужбы казаков, замминистра финансов С.А. Королев в то же время отмечал, что предоставление льгот для них может быть лишь на общих основаниях, в соответствии с существующим законодательством [9, л. 118].

Некоторыми субъектами РФ такая логика возрождения была воспринята очень негативно. Так, Главным государственно-право- вым управлением Президента Республики Татарстан в Миннац России было направлено заключение, в котором отмечалось, что «возрождение» в предлагаемом виде может привести к серьезным, в том числе вооруженным, конфликтам в различных регионах страны «сословия казаков» с остальным населением [18, с. 89-90]. Председатель Госсобрания - Эл Курултая Республики Алтай В.И. Чантынов направил записку «К вопросу о казачестве и предложения к проекту Федерального закона “О казачестве"» [7, л. 154158] зампредседателю Правительства РФ С.М. Шахраю, в которой отмечал, что к возрождению казачества в стране нужно подходить «с исключительной осторожностью...» во избежание межнациональной розни и конфликтов, так как казаков в Горном Алтае местное население воспринимает как чужих, пришлых людей, появившихся «...c колонизаторскими, карательными целями...» [7, л. 155]. Более того, современные казаки являются «полувоенизированным формированием», что может еще более усилить конфликтность в регионе [7, л. 155-156]. Непосредственно законопроект «О казачестве» В.И. Чантынов предлагал дополнить положением, согласно которому возрождение казачества возможно было бы не во всей России, а лишь там, где они (казаки) исторически были представлены [7, л. 157-158]. Противоречия, которыми изобилует данная записка, говорят, скорее всего, о том, что подготовлена она была с целью укрепления «этнического алтайского компонента» в республике, а не на основе существующего законодательства.

Президентский Указ от 9 августа 1995 г. № 835 «О государственном реестре казачьих обществ в Российской Федерации» [16] стал новым этапом реализации госполитики в отношении казачества. Этим Указом утверждалось «Временное положение о государственном реестре казачьих обществ в Российской Федерации», в котором казачьи организации делились на те, которые брали на себя обязательства по несению госслужбы и регистрировались в Миннаце России, и те, законодательной основой деятельности которых оставался Закон РФ «Об общественных объединениях» [15], они регистрировались в органах юстиции. Теперь согласно «Временному по- 
ложению» казачество делилось на «реестровое» и «общественное» с закреплением за первым статуса госструктуры. П. 4. «Временного положения» утверждал неэтнический статус реестровых казачьих обществ тем, что подтверждал добровольный характер вступления в них с целью несения госслужбы [16]. При этом в казачьих обществах устанавливалась четкая организационная структура с определенной численностью и составом, а также системой отчетности по несению госслужбы для Миннаца России и Совета по делам казачества при Президенте РФ.

В логике развития положений Указа «О государственном реестре казачьих обществ в Российской Федерации» 16 апреля 1996 г. Президентом РФ подписывается ряд правовых актов, в которых уточнялись, структурировались и регламентировались различные сферы деятельности казачьих обществ. Президентский Указ № 562 «Вопросы Главного управления казачьих войск при Президенте Российской Федерации (ГУКВ)» утверждал Положение о ГУКВ. Указом № 563 «О порядке привлечения членов казачьих обществ к государственной и иной службе» было утверждено Положение о привлечении казаков к госслужбе и определены виды службы: военная служба, охрана госграницы посредством создания общественных формирований, производство и поставка сельхозпродукции и продовольствия для Вооруженных сил и др. Указом № 564 «Об экономических и иных льготах, предоставляемых казачьим обществам и их членам, взявшим на себя обязательства по несению государственной и иной службы» определялся широчайший круг льгот и привилегий для членов казачьих обществ [17].

Следующим важным шагом по реализации государственной политики в отношении казачества должно было стать принятие федерального закона, регламентирующего дальнейшее развитие казачьего движения. Для его разработки распоряжением Администрации Президента РФ от 7 мая 1996 г. № 931 была создана рабочая группа и определено рабочее название закона - «О российском казачестве». Через месяц, 11 июня 1996 г., в Госдуму РФ поступает проект еще одного федерального закона - «О казачестве», - подготовленный депутатами Л.А. Иванченко (КПРФ), А.Г. Мар- тыновым (НДР), С.В. Сычевым (ЛДПР) и В.П. Зволинским (независимый депутат). Вокруг этих законов в Государственной Думе разгорелись жесточайшие споры, выливающиеся зачастую в достаточно радикальные заявления. Так, заместитель Председателя Госдумы М.3. Юрьев в письме на имя председателя Комитета Госдумы по делам федерации и региональной политики Л.А. Иванченко подчеркивал «нецелесообразность» и даже вредность принятия законопроекта «О казачестве», объясняя это тем, что современные казачьи организации больше похожи на политические движения и в «национально-культурном» отношении не имеют ничего общего с казачьими войсками Российской империи. Если же в конце XX в. пытаться возрождать сословную структуру общества, то это рано или поздно приведет к трансформации казаков в «агрессивный люмпенский элемент» [18, с. 91].

В ходе работы пленарного заседания Государственной Думы 18 июля 1996 г. было предложено образовать согласительную комиссию по доработке законопроекта на основе двух проектов: «О российском казачестве» и «О казачестве». Однако в постановлении № 593-II ГД, принятом по итогам работы этого заседания, было зафиксировано, что за основу берется законопроект «О казачестве», что автоматически снимало законопроект «О российском казачестве» с последующего рассмотрения. В ответ на это Президентом РФ в адрес депутатов ГД РФ было направлено Заключение от 19 марта 1997 г. № Пр-371, констатирующее, что в законопроекте «О казачестве» утверждаются положения, которые противоречат Конституции и другим законам Российской Федерации [18, с. 94].

Через день, 20 июня, депутаты все-таки приняли Федеральный Закон «О казачестве» в третьем чтении. Преамбула Закона была посвящена новому статусу казачества, его государственной службе, традиционному самоуправлению, землепользованию, правам и обязанностям [10, л. 11-15]. Поддерживая мнение Президента РФ, члены Общественного Совета атаманов при ГУКВ 23 июня 1997 г. передали в адрес Председателя Совета Федерации Е.С. Строева и руководителя Администрации Президента В.Б. Юмашева Заявление, называвшее законопроект «О ка- 
зачестве» «неконституционным» и «губительным» для казаков [3, с. 10-11]. В итоге законопроект, принятый Государственной Думой, не был поддержан Советом Федерации.

К концу рассматриваемого периода постепенно сформировалась такая система взаимодействия госструктур с казачеством. В качестве основного организатора и координатора выступало ГУКВ. В субъектах РФ были созданы специальные подструктуры или определены ответственные за работу с казачеством. В Минобороны РФ было сформировано подразделение по казачеству в структуре Главного управления Генштаба; в Управлении пограничной стражи Федеральной пограничной службы - Отдел по службе казачества; в МВД взаимодействие с казачеством возлагалось на Координационный совет и Группу ОМУ штаба ВВ МВД по казачеству; в Миннаце России Отделом по связям с общественными и религиозными организациями по представлению ГУКВ осуществлялась регистрация казачьих обществ; в Минсельхозе был создан Отдел по контролю за выполнением Федеративного договора, вопросам казачества; в Госкомитете по охране окружающей среды и Госкомитете по земельным ресурсам и землеустройству были определены специалисты по работе с казачьими обществами.

За 1996-1998 гг. госреестр казачьих обществ пополнился Волжским, Забайкальским, Уссурийским, Сибирским, Оренбургским, Кубанским, Терским, Енисейским, Иркутским войсковыми казачьими обществами, а также Войсковым казачьим обществом «Всевеликое войско Донское».

Результаты. За рассматриваемый период, с 1994 г. по 1998 г., государственными и региональными органами власти было принято до 100 нормативно-правовых актов. Если документы предшествующего периода, 19911993 гг., прежде всего, были ориентированы на реабилитацию казачества как «репрессированного народа», легитимацию его деятельности через работу различных общественных организаций, созданию различных структур во властных органах по взаимодействию с движением за возрождение казачества, то с 1994 г. начинается активная работа по интеграции казачества в существующую государственную систему. В документах и нормативно- правовых актах 1994-1995 гг. закладывались основы госполитики в отношении казачьего движения, структурировалась управленческая схема и определялись формы взаимодействия государства и казачьих войсковых обществ. За последующие годы (1996-1998), когда активно работало Главное управление казачьих войск при Президенте РФ, было подготовлено до 30 указов и распоряжений Президента РФ, постановления Правительства РФ, большое число инструкций и распоряжений федеральных властных структур, посвященных деятельности казачьих обществ и несению ими государственной службы. ГУКВ принимало активное участие в формировании госреестра казачьих обществ, в который к 1998 г. были внесены 10 войск, 5 отделов, 2 округа, 2 городских казачьих общества (Москва и Санкт-Петербург).

Таким образом, доминирующей тенденцией рассматриваемого периода стал поиск и создание правовых основ деятельности возрождающегося казачества в качестве государственной структуры, посредством формирования государственного реестра (регистра) казачьих обществ, члены которых берут на себя обязанности по несению государственной и иной службы, а также создание правовой базы для организационной и экономической поддержки этих обществ.

\section{СПИСОК ЛИТЕРАТУРЫ}

1. Водолацкий, В. П. Развитие казачества в современном российском обществе (социальный опыт донского казачества) / В. П. Водолацкий. - Ростов н/Д : СКНЦ ВШ ЮФУ, 2011. - 176 с.

2. Документы заседаний Совета Атаманов Союза казаков (списки, доклады, протоколы) // Государственный архив Российской Федерации (ГАРФ). - Ф. 10144. - Оп. 1. - Д. 27. - 122 л.

3. Информационный бюллетень ГУКВ № 3. Государственное становление казачества (19961998 гг.) / отв. ред. Т. В. Таболина. - М. : [б. и.], 1998. $-156 \mathrm{c}$.

4. Казаки России (Прошлое. Настоящее. Будущее). Кн. 1 / отв. ред. Ю. Б. Симченко. - М. : ИЭиА РAH, 1992. $-131 \mathrm{c}$.

5. Козловский, В. В. Факторы и тенденции развития донского казачества / В. В. Козловский, И. О. Кудряков // Социологические исследования. 2014. - № 10 (366). - С. 45-49. 
6. Поручения Правительства Российской Федерации по проблемам казачества и документы по их выполнению. Т. 1 (4 января 1994 - 30 июня 1994) // ГАРФ. - Ф. 10121. - Оп. 2. - Д. 29. - 149 л.

7. Поручения Правительства Российской Федерации по проблемам казачества и документы по их выполнению. Т. 2 (18 января 1995 - 1 июня 1996) // ГАРФ. - Ф. 10121. - Оп. 2. - Д. 152. - 162 л.

8. Поручения Правительства Российской Федерации по проблемам казачества и документы по их выполнению. Т. 3. (9 июня 1995 - 28 июля 1995) // ГАРФ. - Ф. 10121. - Оп. 2. - Д. 154. - 179 л.

9. Поручения Правительства Российской Федерации по проблемам казачества и документы по их выполнению. Т. 4. (26 июля 1995 - 8 ноября 1995) // ГАРФ. - Ф. 10121. - Оп. 2. - Д. 155. - 134 л.

10. Проект Федерального Закона «О казачестве» // [Архив автора. Папка «Проекты законов о казачестве»]. - 46 л.

11. Собрание актов Президента и Правительства РФ. - 1994. - 18 апр. (№ 16). - Ст. 1277.

12. Собрание законодательства РФ. - 1994. № 10. - Ст. 1118.

13. Собрание законодательства РФ. - 1994. № 3. - Ст. 210.

14. Собрание законодательства РФ. - 1994. № 32. - Ст. 3333.

15. Собрание законодательства РФ. - 1995. № 21. - Ст. 1930 .

16. Собрание законодательства РФ. - 1995. № 33. - Ст. 3359 .

17. Собрание законодательства РФ. - 1996. № 17. - Ст. 1953-1955.

18. Таболина, Т. В. Казаки: драма возрождения. 1980-1990-е годы / Т. В. Таболина. - М. : ИЭиА PAH, 1999. - $252 \mathrm{c}$

19. Товченко, Р. Б. Казачество в политическом процессе постсоветской России (на примере Поволжья) : дис. .... канд. полит. наук : 23.00.02 / Товченко Роман Борисович. - М., 2003. - 175 с.

\section{REFERENCES}

1. Vodolatskiy V.P. Razvitie kazachestva v sovremennom rossiyskom obshchestve (sotsialnyy opyt donskogo kazachestva) [Development of the Cossacks in Modern Russian Society (Social Experience of the Don Cossacks)]. Rostov-on-Don, SKNTs VSh YuFU, 2011. $176 \mathrm{p}$.

2. Dokumenty zasedaniy Soveta Atamanov Soyuza kazakov (spiski, doklady, protokoly) [Documents of Meetings of the Council of Cossack Union Atamans (Lists, Reports, Minutes)]. Gosudarstvennyy arkhiv Rossiyskoy Federatsii (GARF) [State Archive of the Russian Federation], F. 10144, Op. 1, D. 27. 1221.
3. Tabolina T.V., ed. Informatsionnyy byulleten GUKV № 3. Gosudarstvennoe stanovlenie kazachestva (1996-1998 gg.) [Newsletter of the Main Department of the Cossack Host of Russia no. 3. State Formation of the Cossacks (1996-1998)]. Moscow, $1998.156 \mathrm{p}$.

4. Simchenko Yu.B., ed. Kazaki Rossii (Proshloe. Nastoyashchee. Budushchee) [Cossacks of Russia (Past. Present. Future]. Moscow, IEiARAN, 1992. $131 \mathrm{p}$.

5. Kozlovskiy V.V., Kudryakov I.O. Faktory i tendentsii razvitiya donskogo kazachestva [Factors and Tendencies of the Development of the Don Cossacks]. Sotsiologicheskie issledovaniya [Sociological Studies], 2014, no. 10 (366), pp. 45-49.

6. Porucheniya Pravitelstva Rossiyskoy Federatsii po problemam kazachestva i dokumenty po ikh vypolneniyu. T. 1 (4 yanvarya 1994 30 iyunya 1994) [Instructions of the Government of the Russian Federation on the Problems of the Cossacks and Documents on Their Implementation. Vol. 1 (January 4, 1994 - June 30, 1994)]. Gosudarstvennyy arkhiv Rossiyskoy Federatsii $(G A R F)$ [State Archive of the Russian Federation], F. 10121, Op. 2, D. 29. 1491.

7. Porucheniya Pravitelstva Rossiyskoy Federatsii po problemam kazachestva i dokumenty po ikh vypolneniyu. T. 2 (18 yanvarya $1995-1$ iyunya 1996) [Instructions of the Government of the Russian Federation on the Problems of the Cossacks and Documents on Their Implementation. Vol. 2 (January 18, 1995 - June 1, 1996)]. Gosudarstvennyy arkhiv Rossiyskoy Federatsii (GARF) [State Archive of the Russian Federation], F. 10121, Op. 2, D. 152. 1621.

8. Porucheniya Pravitelstva Rossiyskoy Federatsii po problemam kazachestva i dokumenty po ikh vypolneniyu. T. 3 (9 iyunya 1995 - 28 iyulya 1995) [Instructions of the Government of the Russian Federation on the Problems of the Cossacks and Documents on Their Implementation. Vol. 3 (June 9, 1995 - July 28, 1995)]. Gosudarstvennyy arkhiv Rossiyskoy Federatsii (GARF) [State Archive of the Russian Federation], F. 10121, Op. 2, D. 154. 1791.

9. Porucheniya Pravitelstva Rossiyskoy Federatsii po problemam kazachestva i dokumenty po ikh vypolneniyu. T. 4 (26 iyulya $1995-8$ noyabrya 1995) [Instructions of the Government of the Russian Federation on the Problems of the Cossacks and Documents on Their Implementation. Vol. 4 (July 26, 1995 - November 8, 1995)]. Gosudarstvennyy arkhiv Rossiyskoy Federatsii (GARF) [State Archive of the Russian Federation], F. 10121, Op. 2, D. 155. 1341.

10. Proekt Federalnogo Zakona «O kazachestve» [Draft Federal Law “On the Cossacks"]. Arkhiv avtora. Papka "Proekty zakonov o kazachestve» [Author's Archive. Folder "Draft Laws on the Cossacks"]. 461. 
11. Sobranie aktov Prezidenta i Pravitelstva $R F$, 1994, April 18, no. 16, art. 1277.

12. Sobranie zakonodatelstva RF, 1994, no. 10 , art. 1118

13. Sobranie zakonodatelstva RF, 1994, no. 3, art. 210.

14. Sobranie zakonodatelstva $R F, 1994$, no. 32, art. 3333 .

15. Sobranie zakonodatelstva $R F, 1995$, no. 21 , art. 1930 art. 3359

16. Sobranie zakonodatelstva $R F, 1995$, no. 33,

\section{Information about the Author}

German O. Macievskiy, Doctor of Sciences (History), Associate Professor, Professor, Department of Philosophy, Cultural Studies and Social Communications, Kuban State University of Physical Culture, Sports and Tourism, Budennogo St., 161, 350015 Krasnodar, Russian Federation, matsievski2004@mail.ru, https://orcid.org/0000-0003-2769-2564

\section{Информация об авторе}

Герман Олегович Мациевский, доктор исторических наук, доцент, профессор кафедры философии, культуроведения и социальных коммуникаций, Кубанский государственный университет физической культуры, спорта и туризма, ул. Буденного, 161, 350015 г. Краснодар, Российская Федерация, matsievski2004@mail.ru, https://orcid.org/0000-0003-2769-2564 